\title{
West Nile Virus Existence in Humans and Mosquitoes in
}

\section{Alexandria Governorate}

Heba A. Abd-el Hady*, Mohamed A. El-Barrawy**, Mona H. Hashish**, Nadia E. Abou ElEla $^{\star * \star}$, Nawal M. Yossef*

\begin{abstract}
West Nile virus (WNV) is a zoonotic mosquito-transmitted arbo-virus belonging to the genus flavivirus in the family Flaviviridae. The aim of the present study was to determine the role of WNV in human cases with fever of unknown etiology and to study the immune status to WNV among healthy humans. In addition, the prevalence of WNV in Culex mosquito vectors was estimated. The study included 210 patients (with undiagnosed acute febrile illness for more than 2 days; admitted to Alexandria Fever Hospital during a period of one year), 200 healthy humans (volunteer blood donors accepted for donation at Alexandria Regional Blood Bank) and 200 mosquito pools (from six administrative districts of Alexandria). WNV antibodies of the IgM and IgG types were detected in patients and healthy humans using enzyme linked immunosorbent assay (ELISA), respectively. WNV was detected in mosquito by virus isolation on Vero cell culture. WNV IgM antibodies were detected in $56(26.7 \%)$ patients, while WNV IgG antibodies were detected in $42(21 \%)$ out of the 200 healthy humans. WNV was isolated from $27(13.5 \%)$ out of the 200 mosquito pools. Patients in the age groups 20 - and $40-$ had the highest percentages of WNV IgM antibodies. The highest WNV IgM antibodies positivity rates occurred in spring and in fall seasons. Male samples had significantly higher percentage of the IgG antibodies than female samples (25.6\%Vs $13.3 \%)$. Conclusion: WNV should not be overlooked in diagnosis of fevers as the main problem may be not due to the disease itself but the economic consequences from the hospitalization of indeclinable numbers of patients. WN disease can be difficult to monitor; almost unpredictable and appearing unexpectedly, this disease has to be surveyed and the viral circulation rapidly detected so that the sanitary authorities can take protective measures.
\end{abstract}

\section{INTRODUCTION}

West Nile virus (WNV) is a zoonotic icosahedral symmetry of $50 \mathrm{~nm}$ in mosquito-transmitted arbo-virus belonging diameter, with no surface projections or to the genus flavivirus in the family spikes. The outermost layer contains the Flaviviridae. Virions of WNV have viral envelope and membrane proteins

\footnotetext{
* Animal Health Research Institute

** Microbiology Department, High Institute of Public Health, Alexandria University

${ }^{* * *}$ Vector Control and Pesticides Risks, Tropical Health Department, High Institute of Public Health, Alexandria University
} 
embedded in a lipid bilayer, forming the envelope of the virion. Inside the envelope is the nucleocapsid core, which consists of multiple copies of the capsid protein and genomic RNA (single-stranded of plussense polarity). ${ }^{(1)}$ WNV infections are classified as either neuroinvasive or nonneuroinvasive. While most humans infected with WNV are asymptotic, some may develop an influenza-like illness, manifested by sudden onset of high fever, headache, fatigue, malaise, muscle pain, and weakness after an incubation period of 3-14 days, and symptoms usually last 3-6 days. (2) Fortunately, neuroinvasive disease develops in $<1 \%$ of WNV infected persons for example, in such forms as meningitis, encephalitis, or paralysis. ${ }^{(3)} \quad$ Until 1999, WNV had a medical attention as the cause of febrile illness and sporadic encephalitis in parts of Africa, Asia, and Europe. After the surprising detection of WNV in New York City in 1999, the virus has spread dramatically westward across the United
States (U.S.), southward into Central America and the Caribbean, and northward into Canada, resulting in the largest epidemics of neuroinvasive WNV disease ever reported. From 1999 to 2004, over 7000 neuroinvasive WNV disease cases were reported in the United Sates. ${ }^{(4)} \mathrm{WN}$ virus is endemic in tropical areas, particularly India and Africa, where local proliferation of infected mosquitoes can lead to epizootics presenting $\mathrm{WN}$ virus as a potential emerging human-pathogenic virus. ${ }^{(5)}$ WNV is maintained in an enzootic cycle involving culicine mosquitoes and birds. In Egypt, the virus was detected in, Cx antennatus, $C x$ pipiens, $C x$ univittatus, as well as Argas hermannia (soft tick). ${ }^{(4,6)}$ Mosquitoes become infected with WNV when they feed on a bird carrying the virus in its blood. Within 10-14 days of becoming infected, a mosquito can transmit the virus in its saliva to another bird or animal. During the bird-mosquito-bird cycle, viral amplification occurs, increasing the 
likelihood of WNV infection when an individual is bitten. ${ }^{(7,8)}$

Serologic testing is the mainstay of diagnosis of WNV infection. Antibodycapture-enzyme-linked immuno sorbent assay (ELISA) of immunoglobulin (lg) $M$ in cerebrospinal fluid (CSF) provides strong evidence of recent WNV infection as it does not readily cross the blood-brain barrier, so its presence in the (CSF) indicates infection of the central nervous system (CNS). Its sensitivity is nearly $100 \%$ after the eighth day of illness. However, in patients with WNV neuroinvasive disease, specific $\lg M$ is almost always detectable in serum and CSF by the time CNS symptoms begin. ${ }^{(9)}$ $\lg \mathrm{M}$ is detectable in serum of nearly $36 \%$ of patients who have survived WNV encephalitis at 12 months post onset and about $20 \%$ at 16 months post onset. The virus can be recovered from the blood of immunocompetent febrile patients for up to 10 days, with an average duration of seven days. Peak viremia occurs four to eight days post-infection. It can be found as late as 22 to 28 days after infection in immunocompromised patients. ${ }^{(10,11)}$ WNV is best isolated in cell culture or suckling mice and identified by indirect immunofluorescence assay with specific monoclonal antibodies or by reverse transcriptase-polymerase chain reaction (RT - PCR). ${ }^{(12)}$

The aim of the present study was to determine the role of WNV in human cases with fever of unknown etiology and to study the immune status to WNV among healthy humans. In addition, the prevalence of WNV in Culex mosquito vectors was estimated.

\section{MATERIAL AND METHODS:}

The study was carried out during the period from July 2004 through August 2005 on 210 patients (with undiagnosed acute febrile illness for more than 2 days; admitted to Alexandria Fever Hospital during a period of one year), 200 healthy 
humans (volunteer blood donors accepted for donation at Alexandria Regional Blood Bank) and 200 mosquito pools (from six administrative districts of Alexandria).

After taking an informed consent, each patient was interviewed by use of a structured questionnaire concerning age, sex, residency, and other variables related to exposure to mosquitoes and domestic animals and/or birds. Three $\mathrm{ml}$. blood were collected from each patient and healthy blood donor. Blood samples were separated within 2 hours of collection and sera were stored at $-70^{\circ} \mathrm{C}$ until final laboratory analysis. Serum samples were tested for the presence of WNV by:

- Detection of anti-WNV antibodies of the IgM type by ELISA technique in samples obtained from patients. An $\lg \mathrm{M}$ capture assay to detect virus specific $\lg M$ ( $\mu$ chain) antibody was performed according to the standard operating procedures (SOP): SER-100 obtained from U.S Naval Medical
Research Unit 3 (NAMRU-3), Cairo, Arab Republic of Egypt. ${ }^{(13)}$

- Detection of anti-WNV antibodies of the IgG type for samples obtained from healthy humans. An ELISA technique for detection of virus specific $\lg G(¥$ chain) antibody was carried out according to NAMRU-3 SOP:SER101.(14)

Adult mosquitoes were collected using light traps and sucking tubes for those at resting sites and houses, respectively. ${ }^{(15)}$ Mosquitoes were placed on ice upon collection and transported to the laboratory to be identified on the basis of sex and species.(16) Female culex mosquitoes were pooled (50 individuals each) in labeled tubes according to date and site of collection. Pools were then stored at $-70^{\circ} \mathrm{C}$ until processing for detection of WNV by isolation onto Vero cell culture at the Central Laboratory for Evaluation of Veterinary Biologics in Cairo. WNV isolation from mosquitoes: (17) 
Pools of mosquitoes were ground in 2 $\mathrm{ml}$ of BA-1 diluent (1x medium199 with Hanks' balanced salt solution, $0.05 \mathrm{M}$ Tris buffer [pH 7.0], 1\% bovine serum albumin, $0.35 \mathrm{~g}$ of sodium bicarbonate per liter, 100 $\mu \mathrm{g}$ of streptomycin per liter, $1 \mu \mathrm{g}$ of amphotrecin B per $\mathrm{ml}$ ) with cold mortars and pestles. The homogenate was centrifuged in Eppendorf tubes at 14.000 rpm for 3 min (Sigma centrifuge 4-15C and plate rotor 2 x 96; Qiagen). The supernatant obtained was tested for virus by inoculating Vero cell cultures. Samples were allowed to adsorb for $1 \mathrm{hr}$ at $37^{\circ} \mathrm{C}$ with gentle swirling every $15 \mathrm{~min}$. Eagles' minimal essential medium (MEM) with $2 \%$ fetal calf serum, $100 \mathrm{U} / \mathrm{ml}$ penicillin, 200 $\mu \mathrm{g} / \mathrm{ml}$ streptomycin and $12.5 \mathrm{U} / \mathrm{ml}$ nystatin was then added to the infected cells. Cells were monitored daily for 7 days for cytopathic effect (CPE) in the form of rounding-up of cells, granulation, and detachment. Infected cells that showed CPE were evaluated by RT-PCR. A sample $(100 \mu \mathrm{l})$ of the supernatant was passaged onto Vero cell monolayer to confirm WNV. Cells from monolayer that didn't show CPE were passaged on to fresh Vero cell monolayer for 3 blind passages. Cells that didn't show CPE after these passages were considered negative for WNV.

RT-PCR: Medium was removed from wells showing CPE. The RNA was extracted from $350 \mu \mathrm{l}$ of homogenized sample medium with RNeasy (Qiagen, Valencia, Calif.) according to the manufacturer's protocol and resuspended in $30 \mu \mathrm{l}$ of RNase-free water. The primer pair WN240-Kun848 (respective genome positions 5': 848 and 1,645) was used to synthesize an 800-bp product in the $E$ gene region. The resulting DNA fragment was visualized on $1.5 \%$ agarose gel stained with ethidium bromide. ${ }^{(18)}$

\section{RESULTS}

In the current study, among the 210 studied patients WNV IgM antibodies were 
detected in 56 (26.7\%), while WNV IgG antibodies were detected in $42(21 \%)$ out of the 200 healthy humans. WNV was isolated from 27 (13.5\%) out of the 200 mosquito pools. Patients in the age groups 20- and 40- had the highest percentages of WNV IgM antibodies, where it was positive in 20 (39.2\%) and 10 (38.5\%), respectively; yet statistically nonsignificant, (Table 1). Female patients had higher rate 28 (30.8\%) of WNV IgM antibodies than males $28(23.5 \%)$, (Table 2). As regards residence, $45(80.4 \%)$ of patients seropositive for WNV IgM were from rural areas, (Table 3). The highest WNV IgM antibodies positivity rates occurred in spring (51.5\%) and in fall $(50 \%)$ seasons. This was significantly higher than that detected in summer (16.8\%). The antibodies were not detected in any patients during winter, (Table 4). WNV IgM antibodies were significantly positive in $7 \%, 23.2 \%$, and $33.9 \%$ of patients presenting with diarrhea, vomiting, and headache, respectively (Table 5). Most of the seropositive patients 27 (48.2\%) had low grade fever $\left(37.5^{\circ}-\mathrm{C}\right)$. On the other hand, most seronegative patients 61 (39.6\%). had fever of $\left(39.0-40.0^{\circ} \mathrm{C}\right)$. However, this result was not statistically significant, (Table 6). Concerning WNV IgG antibodies, they were detected in 7 (33.3\%) out of 21 aged 10 to less than 20 years, while they occurred in $13(23.6 \%)$ out of 55 healthy donors in the age group 20 to less than 30 years, no statistically significant difference was found, (Table 7). However, male samples had significantly higher percentage of the $\lg G$ antibodies as out of 125 samples collected from males, $32(25.6 \%)$ were positive while in female samples, only $10(13.3 \%)$ out of 75 samples were positive, (Table 8). For mosquito samples, the 27 pools positive for WNV were distributed according to the site of collection. WNV was isolated from 10 (25\%), 2 (20\%), $12(15 \%)$, and $3(6 \%)$ pools out of $40,10,80$, and 50 mosquitoes 
pools collected from El-Montazah, El- Most febrile patients are evaluated by Gomrok, El-Amriah, and Borg El-Arab clinical laboratory methods only for districts, respectively. This result was not statistically significant, (Table 9).

\section{DISCUSSION}

WNV has spread very extensively in a few years and is now emerging largely on the American Continent. During 19992005 , approximately 19,706 cases of WNV disease, including 785 deaths, were reported in the $\mathrm{U}$. S. It is suggested that after many years or even decades, WNV will likely achieve an ecological/epidemiological equilibrium resembling that of the St.Louis encephalitis virus. This would mean regional or multifocal enzootic/epizootic WN viral activity and modest numbers of scattered clinical cases occurring most years, punctuated by occasional outbreaks. ${ }^{(19)}$

In Egypt, as in many other African countries, arboviral infections are rarely considered when evaluating patients with acute, undifferentiated febrile illnesses. brucellosis and typhoid fever. Since many patients with arboviral illnesses initially have acute febrile syndromes, their diagnosis is difficult without confirmatory laboratory tests. However, these tests are difficult to perform in part due to unavailability of specific laboratory tests, equipment, and also the limited economic resources in many countries of the region. Therefore, this study was conducted to determine the role of WNV in patients with fever of unknown etiology. In addition, the immune status of the general population to WNV was tested. WNV was also sought for in Culex mosquitoes collected from different districts of Alexandria Governorate.

Among the 210 serum samples collected from patients with undiagnosed fever in this study, anti-WNV IgM was detected in 56 (26.7\%) samples. In the U.S., where most outbreaks were reported 
over the past 10 years, it was recorded that in 2002, 80 human specimens were submitted for testing, 31(38.8\%) patients tested positive for WNV. Three (6.3\%) out of 48 human specimens tested positive for patients in 2003 , while in $2004,50 \%$ of the reported human disease cases to the ArboNET were reported as WNV fever. In 2005 and in 2006 the reported WNV fever cases were $54 \%$ and $61 \%$, respectively. ${ }^{(20)}$ In Tunisia, during an outbreak of WNV infection out of 64 consecutive patients who presented with clinical manifestations consistent with WNV disease, 36 (56.3\%) had IgM antibodies against WNV.(21) A higher seroprevalence rate of anti-WNV IgM was documented during an outbreak of acute febrile illness reported from the Kapalata military camp in Kisangani, the Democratic Republic of Congo. A total of 35 sera collected from the military patients in the acute phase were tested for the presence of $\operatorname{lgM}$ against vector-borne agents. Serum $\operatorname{lgM}$ antibodies against
WNF virus were found in 23 patients $(66 \%) .{ }^{(22)}$

WNV amplification occurs in the birdmosquito-bird cycle until early fall, when female mosquitoes begin diapause and infrequently bite. Many environmental factors affect this viral amplification cycle (for example, weather or climate, host and vector predators and parasites, and host immune status). When environmental conditions promote significant amplification, sufficient numbers of "bridge vector" mosquito-mosquito that bite both humans and birds, become infected in the late summer and then pose an infection threat to humans. Year-round transmission is possible in more tropical climates. In northern Egypt, the climate and weather patterns are more akin to those typical of southern Europe. Warm, wet summers are typical, but droughts frequently occur, and when they do, it's mostly in late summer and early fall. Outbreaks of WNV routinely occur at that time. (6) In this study, anti-WNV 
IgM positivity was highest in spring (51.5\%) and in fall $(50 \%)$ followed by summer (18.6\%). High seroprevalence IgM levels ranging from $0 \%$ to $73 \%$ were found in the southern region of Israel (Eilot region) in the fall and winter of 1999-2000.(23)

The signs and symptoms of the disease are not specific. In the current study, $42.9 \%$ of the seropositives for antiWNV IgM had abdominal pain, 33.9\% had headache, $23.2 \%$ had vomiting and general body ache and weakness, $12.5 \%$ had cough. Diarrhea and constipation each occurred in $7 \%$ of the seropositive patients. Stiffness of neck was seen in only $5.4 \%$ of the seropositive population. A study from Romania showed high prevalence of fever and headache but noted only $5 \%$ rash, $11 \%$ gastrointestinal symptoms, and $2.4 \%$ lymphadenopathy. Differences in study population and case definitions, as well as methods of data collection, may account for such discrepancies. ${ }^{(24)}$ In a study conducted in Israel, fever, headache, and change in level of consciousness were the most frequent findings; rash was less frequent. Fever $\geq 38^{\circ} \mathrm{C}$ was almost universally present. Sixty percent of the patients had fever above $39^{\circ} \mathrm{C}$ and $20 \%$ had fever above $40^{\circ} \mathrm{C}$. Headache, myalgia, chills, and rash were common, as were gastrointestinal complains such as abdominal pain and diarrhea. (25)

In the present study, it was observed that, most suspected patients (seropositives as well as seronegatives) admitted to the Fever Hospital were from rural areas and having low income (most of them had no permanent work). They often kept animals (mostly birds, sheep, and cows) inside their homes. These circumstances created environmental conditions suitable for propagation of mosquitoes. In 2000, a study in Jordan reported that lower family income $(<100$ Jordanian dinars), presence of domestic animals within the house, and presence of mosquito bites on examination seemed to 
be related to a higher prevalence of infection with WNV. The infection rate among participants was approximately $8 \%$. The rate among female participants (9.7\%) was statistically insignificant more than double that among males (4.0\%), and that was explained by their likelihood of spending most of their time (all are housewives) caring for domestic animals in places not protected from mosquitoes. (26)

In this work, 200 serum samples from healthy humans were tested for detection of anti- WNV IgG by ELISA. The antibodies were found in $42(21 \%)$ of the healthy population. Thirty two males (25.6\%) and $10(13.3 \%)$ females were seropositives for the $\lg G$ antibodies. Concerning age, the immunoglobulins were detected in 7 (33.3\%) among age group 10- years, 13 (23.6\%) among those of age 20-, 4 (20.5\%), 11(17.2\%), and $2(12.5 \%)$ among ages of 40-, 30- and 50-, respectively. In Egypt 2007, a study was carried out to identify the possible microbial causes (bacterial, viral, and fungal) of meningitis and encephalitis cases in El-Behera, Kafr El-Sheikh, and Alexandria Governorates. The study detected high rate of exposure to WNF virus. Anti-WNV IgG antibodies were detected in $6.9 \%$ of the tested population.(27) In the Nile River Valley of Egypt, blood specimens were obtained from 915 persons representing 190 study households (to determine the prevalence of antibody to arboviruses, rickettsiae, and hantaan-like viruses). Enzyme immunoassay testing showed that the overall prevalence of $\lg G$ antibody was $20 \%$ to WNV. The prevalence of agentspecific antibody tended to increase with age. (28) Another study was conducted to estimate the prevalence of selected arboviral antibody among a sample of school children from 4 villages in the Bilbeis area of the Nile River Delta. Blood specimens were obtained from subjects aged 8 to 14 years. The prevalence of antibody was $3 \%$ for WNV.(29) However, a 
strikingly high IgG seroprevalence reaching $59 \%$ has been reported from Sudan in 1989. Antibody prevalences tended to increase with age, and were about the same for males and females. ${ }^{(30)}$

In the current study, 200 mosquito pools were collected and identified as female culex from March through November, 2005. The pools were tested by virus isolation technique. The virus was isolated from 27 (13.5\%) out of the 200 pools. Unfortunately, there is no recent available data in Egypt about the existence of WNV in mosquitoes. However, in an intensive study in 1951-1954, virus was only isolated in $1.7 \%$ of pools tested. (20) In New York City, in 1999, among 967 pools (a total of 24,068 adult mosquitoes from 23 species were tested in 967 pools) of different mosquito species, collected from September to October 1999, the virus was isolated from only 2 pools of Culex pipiens. $^{(31)}$ A slightly higher result was obtained during the epizootic WNV activity that was first detected in Connecticut during September and October 1999 characterized by substantial die-offs among American crows, Corvus brachyrhynchos, where fourteen isolates of WNV were obtained from four mosquito species, from which, 5 were from Culex pipiens. (32) In 2001 collective data from U.S. mentioned that 841 mosquito pools and 4,368 individual female mosquitoes were submitted for testing. Three pools of Culex mosquitoes tested positive. In 2002, 84 mosquito pools tested positive for WNV out of 1315 mosquito pools and 10,355 individual female mosquitoes. Forty-nine mosquito pools tested positive out of 2,114 pools and 20,062 individual females in 2003. In 2004, 42 pools tested positive out of 1,671 pools and 28,929 individual females. (33)

In conclusion WNV should not be overlooked in diagnosis of fevers as the main problem may be not due to the disease itself but the economic 
consequences from the hospitalization of this disease has to be surveyed and the indeclinable numbers of patients. WN viral circulation rapidly detected so that the disease can be difficult to monitor; almost sanitary authorities can take protective unpredictable and appearing unexpectedly, measures.

Table (1): Distribution of anti-WNV antibodies IgM among 210 patients with undiagnosed fever in relation to age.

\begin{tabular}{|c|c|c|c|c|c|c|c|}
\hline \multirow{3}{*}{ Age } & \multicolumn{4}{|c|}{$\lg M$} & \multirow{2}{*}{\multicolumn{2}{|c|}{ Total }} & \multirow[b]{2}{*}{ Test } \\
\hline & \multicolumn{2}{|c|}{ Negative } & \multicolumn{2}{|c|}{ Positive } & & & \\
\hline & No. & $\%$ & No. & $\%$ & No. & $\%$ & \multirow{8}{*}{$\begin{array}{c}X^{2}=11.585 \\
P=0.072\end{array}$} \\
\hline$<10$ & 15 & 83.3 & 3 & 16.7 & 18 & 100 & \\
\hline 10- & 54 & 84.4 & 10 & 15.6 & 64 & 100 & \\
\hline 20- & 31 & 60.8 & 20 & 39.2 & 51 & 100 & \\
\hline 30- & 21 & 75.0 & 7 & 25.0 & 28 & 100 & \\
\hline 40- & $\overline{\overline{16}}$ & 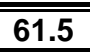 & $\overline{10}$ & 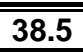 & 26 & $\overline{100}$ & \\
\hline $50-$ & 17 & 73.9 & 6 & 26.1 & 23 & 100 & \\
\hline Total & 154 & 73.3 & 56 & 26.7 & 210 & 100 & \\
\hline
\end{tabular}


Table (2): Distribution of anti-WNV IgM antibodies among 210 patients with undiagnosed fever as regards sex.

\begin{tabular}{|c|c|c|c|c|c|c|c|}
\hline \multirow{3}{*}{ Sex } & \multicolumn{4}{|c|}{$\lg M$} & \multirow{2}{*}{\multicolumn{2}{|c|}{ Total }} & Test \\
\hline & \multicolumn{2}{|c|}{ Negative } & \multicolumn{2}{|c|}{ Positive } & & & \multirow{5}{*}{$\begin{array}{l}X^{2}=1.382 \\
P=0.240\end{array}$} \\
\hline & No. & $\%$ & No. & $\%$ & No. & $\%$ & \\
\hline Male & 91 & 76.5 & 28 & 23.5 & 119 & 100 & \\
\hline Female & 63 & 69.2 & 28 & 30.8 & 91 & 100 & \\
\hline Total & $\overline{154}$ & $\overline{73.3}$ & 56 & 26.7 & 210 & $\overline{100}$ & \\
\hline
\end{tabular}

Table (3): Distribution of anti-WNV IgM antibodies among 210 patients according to the residential area.

\begin{tabular}{|c|c|c|c|c|c|c|c|}
\hline \multirow{2}{*}{$\overbrace{\text { Patients' }}^{\text {Residential areas }}$} & \multicolumn{2}{|c|}{ Urban } & \multicolumn{2}{|c|}{ Rural } & \multicolumn{2}{|c|}{ Total } & \multirow[t]{2}{*}{$\overline{~ T e s t ~}$} \\
\hline & No. & $\%$ & No. & $\%$ & No. & $\%$ & \\
\hline Seropositives & 11 & 19.6 & 45 & $\overline{80.4}$ & 56 & 100 & \multirow{3}{*}{$\begin{array}{l}X^{2}=3.34 \\
P=0.260\end{array}$} \\
\hline Seronegatives & 42 & 27.3 & 112 & 72.7 & 154 & 100 & \\
\hline Total & 53 & 25.2 & 157 & $\overline{74.8}$ & 210 & 100 & \\
\hline
\end{tabular}


Table (4): Distribution of anti-WNV IgM antibodies among 210 patients with undiagnosed fever in relation to season.

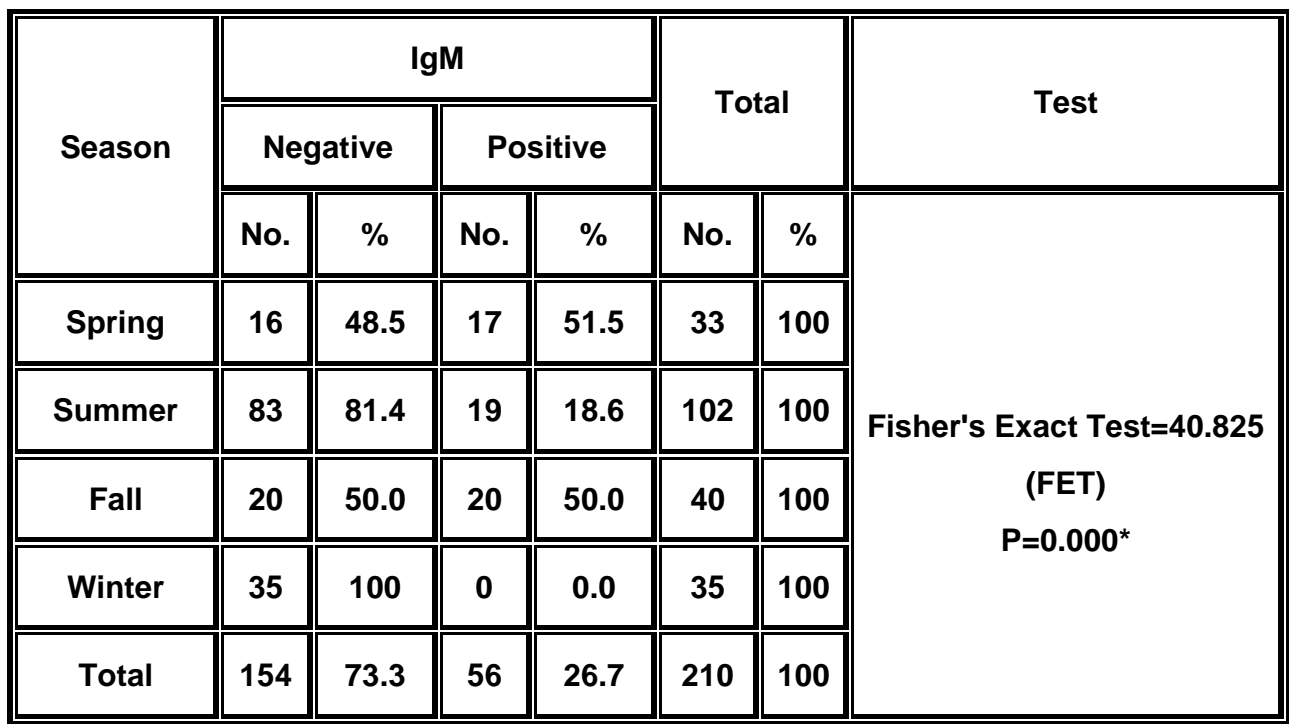

* Significant. 


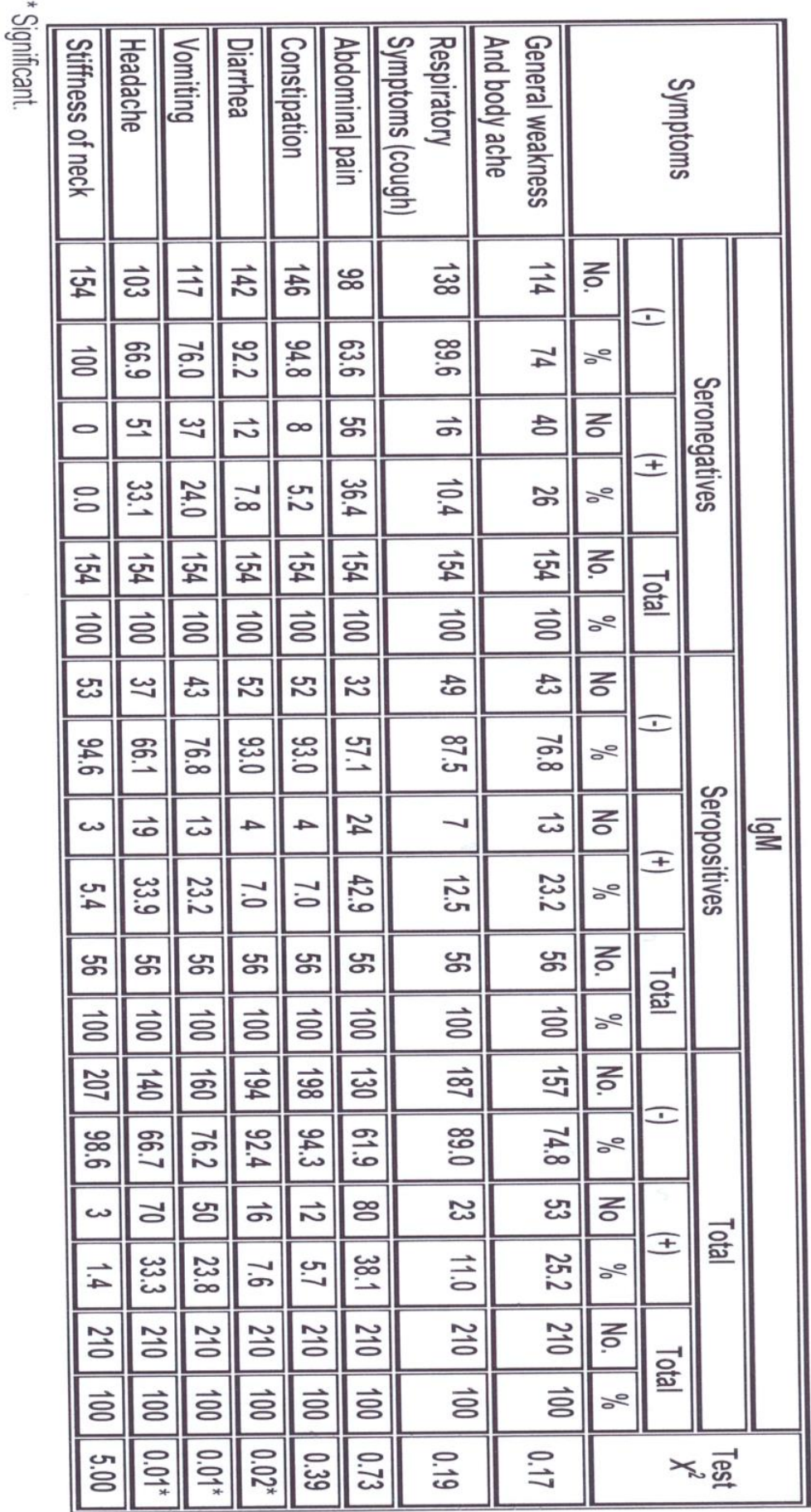

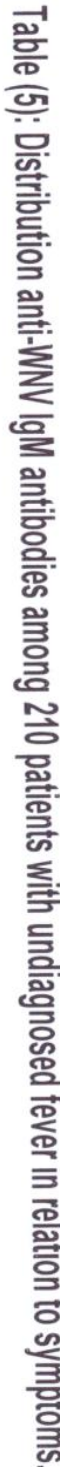


Table (6): Distribution of anti-WNV IgM antibodies among 210 patients in relation to the course of fever.

\begin{tabular}{|c|c|c|c|c|c|c|c|c|c|}
\hline \multirow{2}{*}{$\begin{array}{l}\text { Patients' } \\
\text { group }\end{array}$} & \multicolumn{2}{|c|}{$\left(37.5-^{\circ} \mathrm{C}\right)$} & \multicolumn{2}{|c|}{$\left(38-^{\circ} \mathrm{C}\right)$} & \multicolumn{2}{|c|}{$\left(39-40^{\circ} \mathrm{C}\right)$} & \multicolumn{2}{|c|}{ Total } & Test \\
\hline & No. & $\%$ & No. & $\%$ & No. & $\%$ & No. & $\%$ & $y^{2}-23$ \\
\hline Seropositives & 27 & 48.2 & 14 & 25.0 & 15 & 26.8 & 56 & 26.7 & $P=0.189$ \\
\hline Seronegatives & 56 & 36.3 & 37 & 24.0 & $\overline{61}$ & 39.6 & 154 & 73.3 & \\
\hline Total & 83 & 39.5 & 51 & 24.3 & 76 & 36.2 & 210 & 100 & \\
\hline
\end{tabular}

Table (7): Distribution of anti-WNV IgG antibodies among 200 healthy humans according to age.

\begin{tabular}{|c|c|c|c|c|c|c|c|}
\hline \multirow[t]{3}{*}{ Age } & \multicolumn{4}{|c|}{$\lg G$} & \multirow{2}{*}{\multicolumn{2}{|c|}{ Total }} & \multirow[t]{3}{*}{ Test } \\
\hline & \multicolumn{2}{|c|}{ Negative } & \multicolumn{2}{|c|}{ Positive } & & & \\
\hline & No. & $\%$ & No. & $\%$ & No. & $\%$ & \\
\hline 10- & 14 & 66.7 & 7 & 33.3 & 21 & 100 & \multirow{6}{*}{$\begin{array}{l}X^{2}=3.421 \\
P=0.490\end{array}$} \\
\hline $20-$ & 42 & $\overline{76.4}$ & 13 & 23.6 & 55 & 100 & \\
\hline 30- & 53 & 82.8 & 11 & 17.2 & 64 & 100 & \\
\hline 40- & 35 & 79.5 & 9 & 20.5 & 44 & 100 & \\
\hline 50- & 14 & 87.5 & 2 & 12.5 & 16 & 100 & \\
\hline Total & 158 & 79 & 42 & 21 & 200 & 100 & \\
\hline
\end{tabular}


Table (8): Distribution of anti-WNV IgG antibodies among 200 healthy humans according to sex.

\begin{tabular}{|c|c|c|c|c|c|c|c|}
\hline \multirow{3}{*}{ Sex } & \multicolumn{4}{|c|}{$\lg \mathbf{G}$} & \multirow{2}{*}{\multicolumn{2}{|c|}{ Total }} & Test \\
\hline & \multicolumn{2}{|c|}{ Negative } & \multicolumn{2}{|c|}{ Positive } & & & \multirow{5}{*}{$\begin{array}{l}X^{2}=4.252 \\
P=0.039^{\star}\end{array}$} \\
\hline & No. & $\%$ & No. & $\%$ & No. & $\%$ & \\
\hline Male & 93 & 74.4 & 32 & 25.6 & 125 & 100 & \\
\hline Female & 65 & 86.7 & 10 & 13.3 & 75 & 100 & \\
\hline Total & $\overline{158}$ & 79 & $\overline{42}$ & 21 & 200 & 100 & \\
\hline
\end{tabular}

* Significant.

Table (9): Distribution of WNV among mosquito pools in relation to site of collection.

\begin{tabular}{|c|c|c|c|c|c|c|c|}
\hline \multirow[b]{2}{*}{ Districts } & \multicolumn{2}{|c|}{ Negative } & \multicolumn{2}{|c|}{ Positive } & \multicolumn{2}{|c|}{ Total } & Test \\
\hline & No. & $\%$ & No. & $\%$ & No. & $\%$ & \multirow{9}{*}{$\begin{array}{l}X^{2}=10.58 \\
P=0.102\end{array}$} \\
\hline Shark & 5 & 100 & 0 & 0 & 5 & 100 & \\
\hline Gharb & 10 & 100 & 0 & 0 & 10 & 100 & \\
\hline Wasat & 5 & 100 & 0 & 0 & 5 & 100 & \\
\hline El-Montazah & 30 & 75 & 10 & 25 & 40 & 100 & \\
\hline El-Gomrok & 8 & 80 & 2 & 20 & 10 & 100 & \\
\hline El-Amriah & 68 & 85 & 12 & 15 & 80 & 100 & \\
\hline Borg el-Arab & 47 & 94 & 3 & 6 & 50 & 100 & \\
\hline Total & 173 & 86.5 & 27 & 13.5 & 200 & 100 & \\
\hline
\end{tabular}

\section{REFERENCES}

1. Mukhopadhyay S, Kim BS, Chipman PR, Rossmann MG, Kuhn RJ. Structure of West Nile virus. Science. 2003; 302: 248-52.

2. Solomon T, Vaughn DW. Pathogenesis and clinical features of Japanese encephalitis and West Nile virus infections. Curr Top Microbiol Immunol. 2002; 267: 171-94.

3. Mostashari F, Bunning ML, Kitsutani PT, Singer DA, Nash D, Cooper MJ, et al. Epidimic West Nile encephalitis, New York, 1999: results of householdbased seroepidemiological survey. 
Lancet. 2001; 358: 261-4.

4. Hayes EB, Komar N, Nasci R S, Montgomery SP, O'Leary DR, Campbell GL. Epidemiology and transmission dynamics of West Nile virus disease. Emerg Infect Dis. 2005; 11: 1167-73.

5. Berthet F-X, Zeller HG, Drouet M-T, Rauzier J, Digoutte J-P, Deubel V. Extensive nucleotide changes and deletions within the envelope glycoprotein gene of Euro-African West Nile viruses. J Gen Virol. 1997; 78: 2293-7.

6. Hubalek Z, Halouzka J. West Nile fever--a reemerging mosquito-borne viral disease in Europe. Emerg Infect Dis. 1999;5: 643-50.

7. Turell MJ, Sardelis MR, O'Guinn ML, Dohm DJ. Potential vectors of West Nile virus in North America. Curr Top Microbiol Immunol. 2002; 267: 241-52.

8. Sardelis MR, Turell MJ, Dohm DJ, O'Guinn ML. Vector competence of selected North American Culex and Coquillettidia mosquitoes for West Nile virus. Emerg Infect Dis. 2001; 7: 101822.

9. Martin DA, Muth DA, Brown T, Johnson AJ, Karabatsos N, Roehrig JT. Standardization of immunoglobulin M capture enzyme-linked immunosorbent assays for routine diagnosis of arboviral infections. J Clin Microbiol. 2000; 38: 1823-6

10. Roehrig JT, Nash D, Maldin B, Labowitz A, Martin DA, Lanciotti RS, et al. Persistence of virus-reactive serum immunoglobulin $M$ antibody in confirmed West Nile virus encephalitis cases. Emerg Infect Dis. 2003; 9: 3769.

11. Kapoor H, Signs K, Somsel P, Downes FP, Clark PA, Massey JP. Persistence of West Nile virus (WNV) IgM antibodies in cerebrospinal fluid from patients with CNS disease. J Clin Virol. 2004; 31: 289-91.

12. Hayes EB, Sejvar JJ, Zaki SR, Lanciotti RS, Bode AV, Campbell GL. Virology, pathology, and clinical manifestations of West Nile virus disease, Emerg Infect Dis. 2005; 11: 1174-9.

13. NAMRU-3, Virology Branch. SOPSER100, IgM ( $\mu$ chain) ELISA. Available from: http://namru3.med.navy.mil/

14. NAMRU-3, Virology Branch. SOPSER101G IgM ( $*$ chain) ELISA. Available from: http://namru3.med.navy.mil/

15. WHO. Entomological field techniques for malaria control. Part 1. Learner's guide. 1992; 1-78.

16. Woodring JL, Higgs S, Beaty BJ. Natural cycles of vector borne pathogens. In: Marquardt WC, Beaty $\mathrm{BJ}$, eds. Biology of disease vectors. Boulder (CO): University Press of Colorado; 1996. p. 51-72.

17. Bugbee LM, Forte LR. The discovery of West Nile virus in overwintering Culex pipiens (Diptera: Culicidae) mosquitoes in Lehigh County, Pennsylvania. J Am Mosq Control Assoc. 2004; 20: 326-7.

18. Steinman A, Banet-Noach C, Tal S, Levi O, Simanov L, Perk S, et al. West Nile virus infection in crocodiles. Emerg Infect Dis. 2003; 9:887-8.

19. Bhatnagar J, Guarner J, Paddock C, Shieh W, Lanciotti R, Marfin A, et al. Detection of West Nile virus in formalin-fixed, paraffin-embedded human tissues by RT-PCR: A useful adjunct to conventional tissue-based diagnostic methods. J Clin Virol. 2007; 38 (2): 106-11.

20. Centers for Disease Control and Prevention: West Nile virus statistics, surveillance and control -case count. Available from: 
www.cdc.gov/ncidod/dvbid/westnile/ surv\&control.htm

21. Zeller HG, Schuffenecker I. West Nile Virus: an overview of its spread in Europe and the Mediterranean basin in contrast to its spread in the Americas. Eur J Clin Microbiol Infect Dis. 2004; 23: 147-56.

22. Nur YA, Groen J, Heuvelmans H, Tuvnman W, Copra C, Osterhaus AD. An outbreak of West Nile fever among migrants in Kisangani, Democratic Republic of Congo. Am J Trop Med Hyg.1999; 61(6): 885-8.

23. Israeli Ministry of Health, Jerusalem. Department of Epidemiology Quarterly Report 2000; 2: 6-7.

24. Ceausu E, Erscoiu S, Calistru P, Ispas $\mathrm{D}$, Dorobat $\mathrm{O}$, Homos $\mathrm{M}$, et al. Clinical manifestations in the West Nile virus outbreak. Rom J Virol. 1997; 48: 3-11.

25. Chowers MY, Lang R, Nassar F, BenDavid D, Giladi M, Rubinshtein E, et al. Clinical characteristics of the West Nile fever outbreak, Israel, 2000. Emerg Infect Dis. 2001; 7: 675-8.

26. Batieha A, Saliba EK, Graham R, Mohareb E, Hijazi Y, Wijeyaratne P. Seroprevalence of West Nile, Rift Valley, and Sandfly arboviruses in Hashimiah, Jordan. Emerg Infect Dis. 2000; 6(4): 358-62.

27. Baskharoun MF. Microbiological study on meningitis and encephalitis cases in El-Behera, Kafr El-Sheikh, and Alexandria Governorates. PhD Thesis. High Institute of Public Health. Alexandria University, 2007.

28. Corwin A, Habib M, Watts D, Darwish $\mathrm{M}$, Olson J, Botros $\mathrm{B}$, et al.
Community-based prevalence profile of arboviral, rickettsial, and Hantaan-like viral antibody in the Nile River Delta of Egypt. Am J Trop Med Hyg. 1993; 48(6): 776-83.

29. Corwin A, Habib M, Olson J, Scott D, Ksiazek T, Watts DM. The prevalence of arboviral, rickettsial, and Hantaanlike viral antibody among school children in the Nile River Delta of Egypt. Trans R Soc Trop Med Hyg. 1992; 86(6):677-9.

30. Watts DM, El-Tigani A, Botros BA, Salib AW, Olson JG, McCarthy M, et al. Arthropode-borne viral infections associated with a fever outbreak in the northern province of Sudan. J Trop Med Hyg. 1994; 97: 228-30.

31. Nasci RS, White DJ, Stirling $H$, Oliver J, Daniels TJ, Falco RC, et al. West Nile virus isolates from mosquitoes in New York and New Jersey, 1999. Emerg Infect Dis. 2001; 7(4): 626-30.

32. Andreadis TG, Anderson JF, Vossbrinck CR. Mosquito Surveillance for West Nile virus in Connecticut, 2000: Isolation from Culex pipiens, Cx. restuans, Cx. salinarius, and Culiseta melanura. Emerg Infect Dis. 2001;7(4):670-4.

33. District of Columbia. Department of Health. Health Care Regulation and Licensing Administration. Bureau of Community Hygiene. Animal Disease Prevention Division. Arbovirus surveillance and response plan. Available from: http://doh.dc.gov/doh/lib/doh/informatio n/wnv/pdf/west_nile_plan_2006.pdf- 